\title{
THE COMPONENT COMPOSITION OF MITE AND EPIDERMAL DIAGNOSTIC ALLERGENIC EXTRACTS
}

\author{
A. Ye. Bogomolov \\ National Pirogov memorial medical university, Vinnytsya
}

\begin{abstract}
The aim of our study was to determine the component composition of dust mite and epidermal diagnostic allergens, intended for the diagnosis of sensitization in patients with IgE - mediated allergic diseases. Materials and methods. To study the component composition, we used solutions of extracts of diagnostic allergens MP "Immunolog" (Vinnytsia, Ukraine) - Dermatophagoides pteronyssinus, Dermatophagoides farinae, cat hair, dog hair, sheep wool, which are aqueous-saline solutions of protein-polysaccharide complexes isolated from the respective raw material by extraction with Evans-Koch liquid. The allergen was in liquid form with $2 \mathrm{ml}$ of allergen in brown glass vials, with $1 \mathrm{ml}$ of solution containing 10.000 PNU of allergen. 1 PNU (Protein Nitrogen Unit) is an international unit used to determine the concentration of protein nitrogen in allergens, which is equal to $0.00001 \mathrm{mg}$ of protein nitrogen. Electrophoresis of allergen diagnostic solutions was performed by SDS-PAGE in columns recommended by Rockland Immunochemicals, Inc. (https://rockland-inc.com/sds-page.aspx). The database of www.allergen.org, the official site for the systematic nomenclature of allergens approved by the World Health Organization and the International Union of Immunological Societies (WHO / IUCN), was used to identify allergenic components. Results and discussion. Analysis of spectrograms of diagnostic allergen extracts show the presence of major and minor components in most of the analyzed cases. Thus, for allergens of the mite group, Dermatophagoides pteronyssinus — Der p1 with a molecular mass of $24 \mathrm{kDa}$, Dermatophagoides farinae - Der f1 with a molecular mass of $27 \mathrm{kDa}$, Acarus siro - Aca s13 with a molecular mass of $15 \mathrm{kDa}$ components were determined. For epidermal allergens, a major component of Can f1 (lipocalin) with a molecular mass of $23 \mathrm{kDa}$, a minor component of Can f2 $(19 \mathrm{kDa})$ and Can f3 $(69 \mathrm{kDa})$ were found in dog hair allergen extract, and a major component of Fel d1 with a molecular mass of $38 \mathrm{kDa}$, major component Fel d4 (22 kDa), minor components Fel d2 (69 kDa) and Fel d3 $(11 \mathrm{kDa})$ were found in cat hair allergen extract. For sheep wool allergen it is not possible to estimate the component composition by constructing a spectrogram after electrophoresis of solutions in polyacrylamide gel, as it is a mixture of proteins with similar molecular masses. In addition, a number of diagnostic allergens - dog hair, Dermatophagoides farinae, Dermatophagoides pteronyssinus, contains non-allergenic ballast proteins in solutions.
\end{abstract}

Key words: allergy, allergen extracts, major allergens, minor allergens.

A. Ye. Bogomolov Candidate of Medical Sciences, associate professor of phthisiology, clinical immunology and allergy department, National Pirogov memorial medical university, 21000, Pirogova, 56, Vinnytsya, Ukraine, art.bogomolov@gmail.com Asthma and Allergy, 2020, 2, P. 50-56.

\section{КОМПОНЕНТНИЙ СКЛАД КЛІЩОВИХ ТА ЕПІДЕРМАЛЬНИХ ДІАГНОСТИЧНИХ АЛЕРГЕННИХ ЕКСТРАКТІВ}

\section{А. Є. Богомолов}

Резюме. Метою нашого дослідження було визначити компонентний склад кліщових та епідермальних діагностичних алергенів, призначених для діагностики сенсибілізації у пацієнтів з алергічними захворюваннями, опосередкованими IgE-механізмом. Матеріали та методи. Для вивчення компонентного складу нами були використані розчини екстрактів діагностичних алергенів МП "Імунолог" (Вінниця, Україна) - Dermatophagoides pteronissynus, Dermatophagoides farinae, шерсть кота, шерсть собаки, овеча вовна, які є водно-сольовими розчина-

(C) Bogomolov A. Ye., 2020

www.search.crossref.org

DOI: $10.31655 / 2307-3373-2020-2-50-56$ 
ми білково-полісахаридних комплексів, виділені із відповідної сировини екстракцією рідиною Еванса-Коха. Алерген був у рідкій формі по 2 мл алергену у флаконах з коричневого скла, 1 мл розчину якого містить 10000 ПНУ алергену. 1 PNU (Protein Nitrogen Unit) - це міжнародна одиниця, що використовується для визначення концентрації білкового азоту в алергенах, що дорівнює 0,00001 мг білкового азоту. Електрофорез діагностичних розчинів алергенів проводили методом SDS-PAGE у колонках, рекомендованих Rockland Immunochemicals, Inc. (https://rockland-inc.com/sds-page.aspx). База даних www.allergen.org, офіційного сайту систематичної номенклатури алергенів, затверджена Всесвітньою організацією охорони здоров'я та Міжнародним союзом імунологічних товариств (ВОО3 / МСIT), використовувалася для ідентифікації алергенних компонентів. Результати $і$ обговорення. Аналіз спектрограм діагностичних екстрактів алергенів показав наявність мажорних та мінорних компонентів у більшості проаналізованих випадків. Так, для алергенів кліщів визначено у Dermatophagoides pteronyssinus - Der p1 з молекулярною масою 24 кДа, Dermatophagoides farinae - Der f1 з молекулярною масою 27 кДа, Acarus siro - Aca s13 з молекулярною масою 15 кДа. Для епідермальних алергенів, в екстракті алергенів 3 собачої шерсті виявлено мажорний компонент Can f1 (ліпокалін) з молекулярною масою 23 кДа, мінорний компонент Can f2 (19 кДа) та Can f3 (69 кДа); Fel d1 з молекулярною масою 38 кДа, мажорний компонент Fel d4 (22 кДа), мінорні компоненти Fel d2 (69 кДа) та Fel d3 (11 кДа) були виявлені в екстракті алергенів котячої шерсті. Для алергену овечої вовни неможливо оцінити склад компонентів, побудувавши спектрограму після електрофорезу розчинів у поліакриламідному гелі, оскільки це суміш білків із схожими молекулярними масами. Крім того, ряд діагностичних алергенів - шерсть собаки, Dermatophagoides farinae, Dermatophagoides pteronyssinus, містять в розчинах неалергенні баластні білки.

Ключові слова: алергія, алергенні екстракти, мажорні алергени, мінорні алергени.

А. Є. Богомолов, канд. мед. наук, доцент кафедри фтизіатрії з курсом клінічної імунологї Вінницького національного медичного університету ім. М.І. Пирогова 21018, Україна, Вінниия, вул. Пирогова, 56, email: art.bogomolov@gmail.com «Астма та алергія», 2020, № 2, С. 50-56.

\section{КОМПОНЕНТНЫЙ СОСТАВ КЛЕЩЕВЫХ И ЭПИДЕРМАЛЬНЫХ ДИАГНОСТИЧЕСКИХ АЛЛЕРГЕННЫХ ЭКСТРАКТОВ}

\section{А. Е. Богомолов}

Резюме. Целью нашего исследования было определить компонентный состав клещевых и эпидермальных диагностических аллергенов, предназначенных для диагностики сенсибилизации у пациентов с аллергическими заболеваниями, опосредованными IgE-механизмом. Maтериаль и методы. Для изучения компонентного состава нами были использованы растворы экстрактов диагностических аллергенов МП "Иммунолог" (Винница, Украина) - Dermatophagoides pteronissynus, Dermatophagoides farinae, шерсть кота, шерсть собаки, овечья шерсть, которые являются водно-солевыми растворами белково-полисахаридных комплексов, выделенные из соответствующей сырья экстракцией жидкостью Эванса-Коха. Аллерген был в жидкой форме по 2 мл аллергена во флаконах из коричневого стекла, 1 мл раствора которого содержит 10000 PNU аллергена. 1 PNU (Protein Nitrogen Unit) - это международная единица, используемая для определения концентрации белкового азота в аллергенах, равный 0,00001 мг белкового азота. Электрофорез диагностических растворов аллергенов проводили методом SDS-PAGE в колонках, рекомендованных Rockland Immunochemicals, Inc. (Https://rocklandinc.com/sds-page.aspx). База данных www.allergen.org, официального сайта систематической номенклатуры аллергенов, утверждена Всемирной организацией здравоохранения и Международным союзом иммунологических обществ (ВО3 / МСИО), использовалась для идентификации аллергенных компонентов. Результаты $u$ обсуждение. Анализ спектрограмм диагностических экстрактов аллергенов показал наличие мажорных и минорных компонентов в большинстве проанализированных случаев. Так, для аллергенов клещей определено у Dermatophagoides pteronyssinus — Der p1 с молекулярной массой 24 кДа, Dermatophagoides farinae - Der f1 с молекулярной массой 27 кДа, Acarus siro - Aca s13 с молекулярной массой 15 кДа. Для эпидермальных аллергенов, в экстракте аллергенов из собачьей шерсти обнаружен мажорный компонент Саn f1 (липокалин) с молекулярной массой 23 кДа, минорный компонент Can f2 (19 кДа) и Can f3 (69 кДа) Fel d1 с молекулярной массой 38 кДа, мажорный компонент Fel d4 (22 кДа), минорные компоненты Fel d2 (69 кДа) и Fel d3 (11 кДа) были обнаружены в экстракте аллергенов кошачьей шерсти. Для аллергена овечьей шерсти невозможно оценить состав компонентов, построив спектрограмму после электрофореза растворов в полиакриламидном геле, поскольку это смесь белков с похожими молекулярными массами. Кроме того, ряд диагностических аллерге- 
нов - шерсть собаки, Dermatophagoides farinae, Dermatophagoides pteronyssinus, содержат в растворах неаллергенные балластные белки.

Ключевые слова: аллергия, аллергенные экстракты, мажорные аллергены, минорные аллергены.

А. Е. Богомолов, канд. мед. наук, доцент кафедры фтизиатри с курсом клинической иммунологии Винницкого национального медициского университета им. Н.И. Пирогова 21018, Украина, Винниия, ул. Пирогова, 56, email: art.bogomolov@gmail.com «Астма и аллергия», 2020, № 2, С. 50-56.

Specific diagnostics is an integral component of the route of a patient with suspected allergic disease in modern conditions $[1,2]$. In the structure of allergy, more than $85 \%$ are occupied by IgE - mediated diseases: allergic rhinitis, allergic bronchial asthma, anaphylaxis, clinical forms of food, insect and drug allergies, etc.

The gold standard for determining sensitization for such patients is skin prick testing, which allows you to quickly, inexpensively and, most importantly, in vivo, determine the causative factor or factors in the development of the disease [3-5]. However, one of the global unresolved issues of skin testing remains the standardization of diagnostic allergens. Both in Ukraine and around the world, there are currently no clear uniform requirements for this process, which leads to different approaches to standardization by manufacturers of diagnostic allergens. Attempts to bring this process to uniform requirements and to create reference extracts of allergens from the European Union and the WHO did not bring the expected results $[6,7]$. Thus, in modern conditions, commercial diagnostic extracts of allergens from different manufacturers contain different amounts of major and minor components of allergens, which, in theory, may cause different skin reactions to their introduction.

The aim of our study was to determine the component composition of dust mite and epidermal diagnostic allergens, intended for the diagnosis of sensitization in patients with IgE - mediated allergic diseases.

\section{Materials and methods}

To study the component composition, we used solutions of extracts of diagnostic allergens MP «Immunolog» (Vinnytsia, Ukraine) - Dermatophagoides pteronyssinus (registration certificate № UA / 15013/01/01), Dermatophagoides farinae (registration certificate № UA / 15013/01 / 01), cat hair (registration certificate № UA / 15013/01/01), dog hair (registration certificate № UA / 15013/01/01), sheep wool (registration certificate № UA / 15013/01/01), which are aqueous-saline solutions of protein-polysaccharide complexes isolated from the respective raw material by extraction with EvansKoch liquid. The allergen was in liquid form with $2 \mathrm{ml}$ of allergen in brown glass vials, with $1 \mathrm{ml}$ of solution containing 10.000 PNU of allergen. 1 PNU (Protein
Nitrogen Unit) is an international unit used to determine the concentration of protein nitrogen in allergens, which is equal to $0.00001 \mathrm{mg}$ of protein nitrogen.

Electrophoresis of allergen diagnostic solutions was performed by SDS-PAGE in columns recommended by Rockland Immunochemicals, Inc. (https://rockland-inc. com/sds-page.aspx). The results were scanned and processed using Image Studio Lite ver. 5.2 with the subsequent construction and analysis of spectrograms using GelAnalyzer software ver. 19.1. The database of www. allergen.org, the official site for the systematic nomenclature of allergens approved by the World Health Organization and the International Union of Immunological Societies (WHO / IUCN), was used to identify allergenic components.

The study of the component composition of diagnostic allergens using polyacrylamide gel electrophoresis was performed in the laboratory of "R-Biopharm AG" (Darmstadt, Germany).

\section{Results}

For this purpose, by the technique of polyacrylamide gel electrophoresis, electrophoregrams of the following allergens were obtained: dust mites Acarus siro, Dermatophagoides farinae, Dermatophagoides pteronyssinus, epidermal allergens of animals - cat hair (Lana felis), sheep wool and dog hair (Lana can).

Electrophoregrams and control molecular masses are shown in Fig.1.

Using photometric analysis, a spectrogram of the protein composition of the control masses of the protein fractions was formed. Later all the spectrograms of individual allergens were further compared with it to determine their component composition (Fig. 2).

The spectrograms of the protein composition of the diagnostic allergens Dermatophagoides farinae and Dermatophagoides pteronyssinus are shown in Fig. 3 and Fig. 4.

Analysis of the Dermatophagoides farinae allergen spectrogram showed that in the protein composition of the allergen there is a major component Der f1 with a molecular mass of $27 \mathrm{kDa}-$ cysteine protease (mark 2). In addition, the spectrogram does not have a clearly separated molecular mass of $15 \mathrm{kDa}$, which corresponds to the second important major component of the mite 

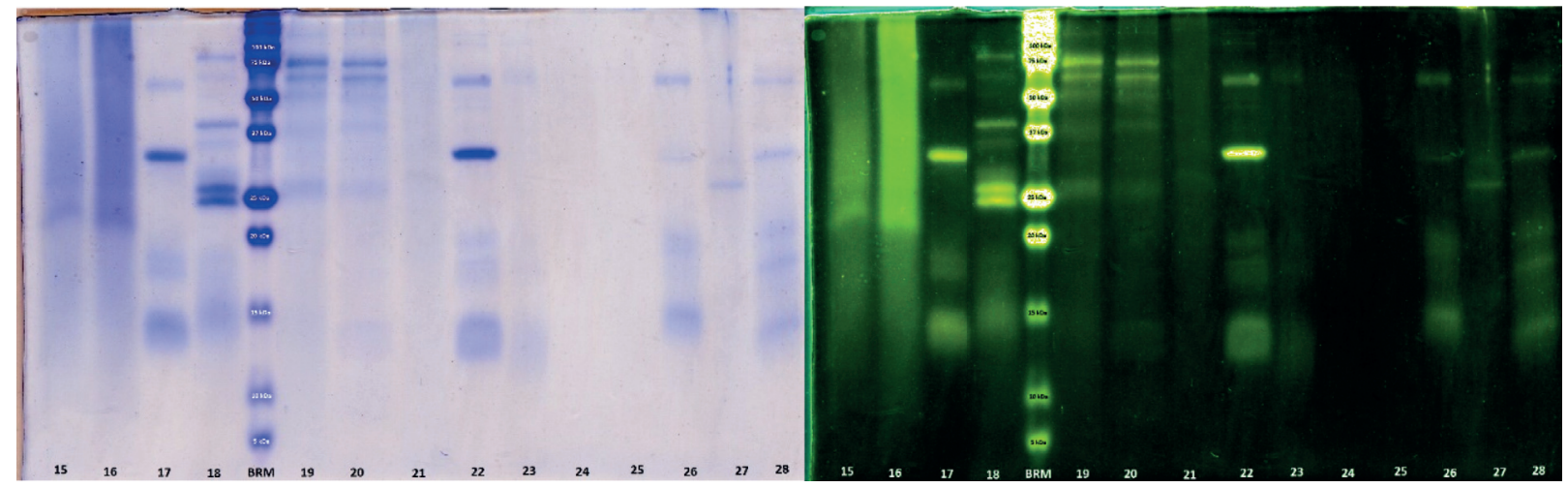

Fig. 1. Electrophoregrams of diagnostic allergens and control masses of protein fractions before (left) and after (right) computer processing for analysis.
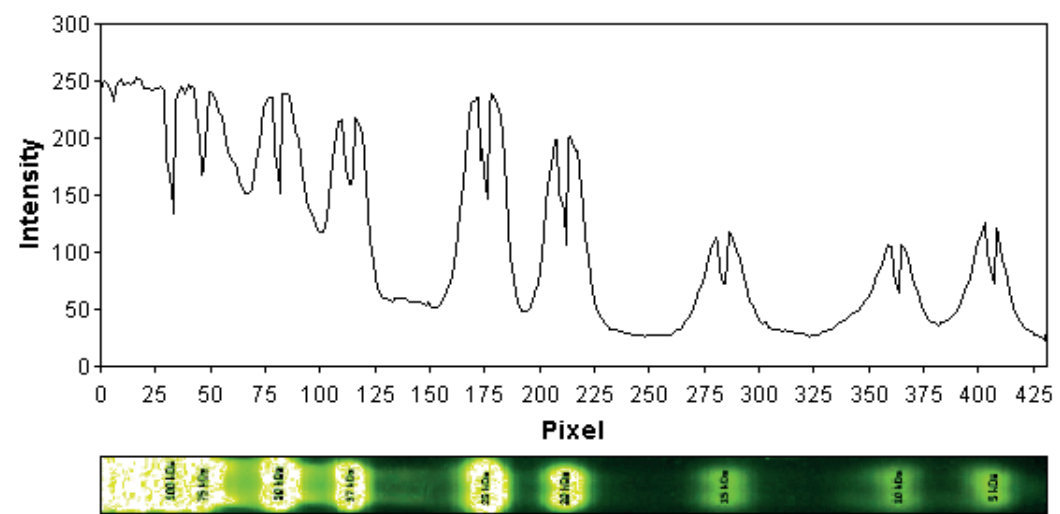

Fig. 2. Spectrogram of protein composition of control masses of protein fractions.

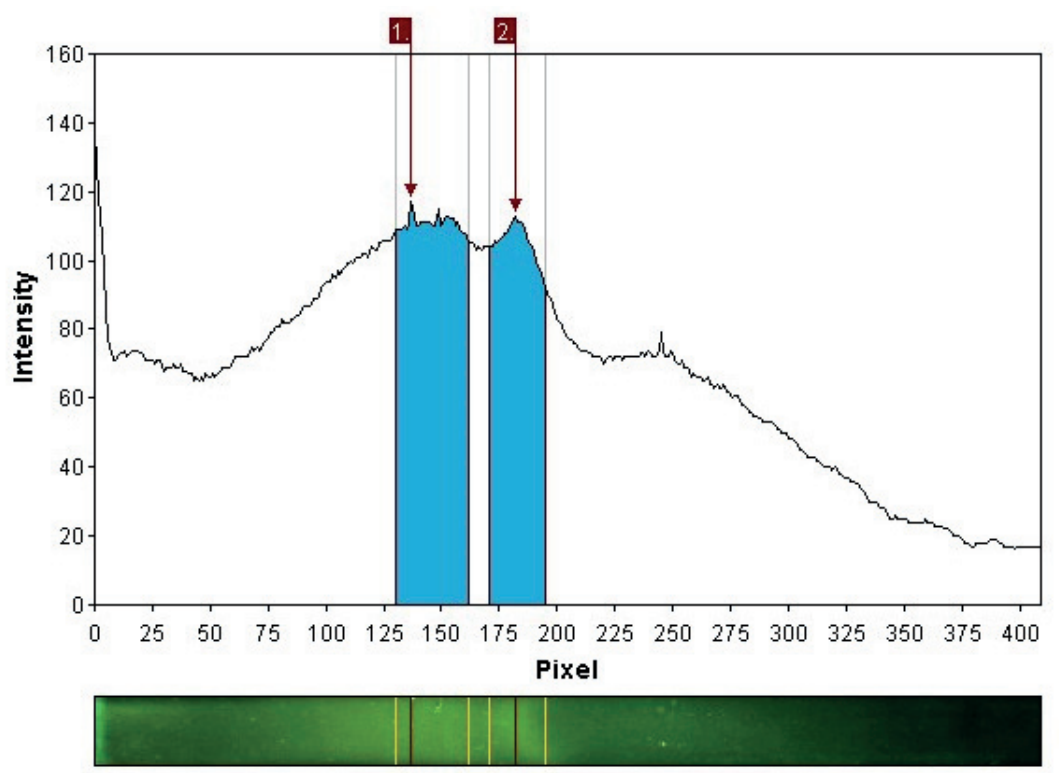

Fig. 3. Spectrogram of the protein composition of the diagnostic allergen Dermatophagoides farinae.

Dermatophagoides farinae - Der $\mathrm{f} 2$ and there are nonallergenic ballast protein components with a molecular weight of $29-33 \mathrm{kDa}$ (mark 1).

Analysis of the Dermatophagoides pteronyssinus allergen spectrogram showed that in the protein composition of the allergen there is a major component Der $\mathrm{p} 1$ with a molecular mass $24 \mathrm{kDa}$ - cysteine protease (mark 2). In addition, the spectrogram does not have a clearly separated molecular mass of $15 \mathrm{kDa}$, which cor- responds to the second important major component of the mite Dermatophagoides pteronyssinus - Der p2 and there are non-allergenic ballast protein components with a molecular mass of $30-100 \mathrm{kDa}$ (mark 1).

The spectrogram of the protein composition of the diagnostic allergen mite Acarus siro is presented in Fig. 4.

Analysis of the spectrogram showed that the protein composition of the allergen contains a major component of Aca s13 with a molecular mass of $15 \mathrm{kDa}-$ 


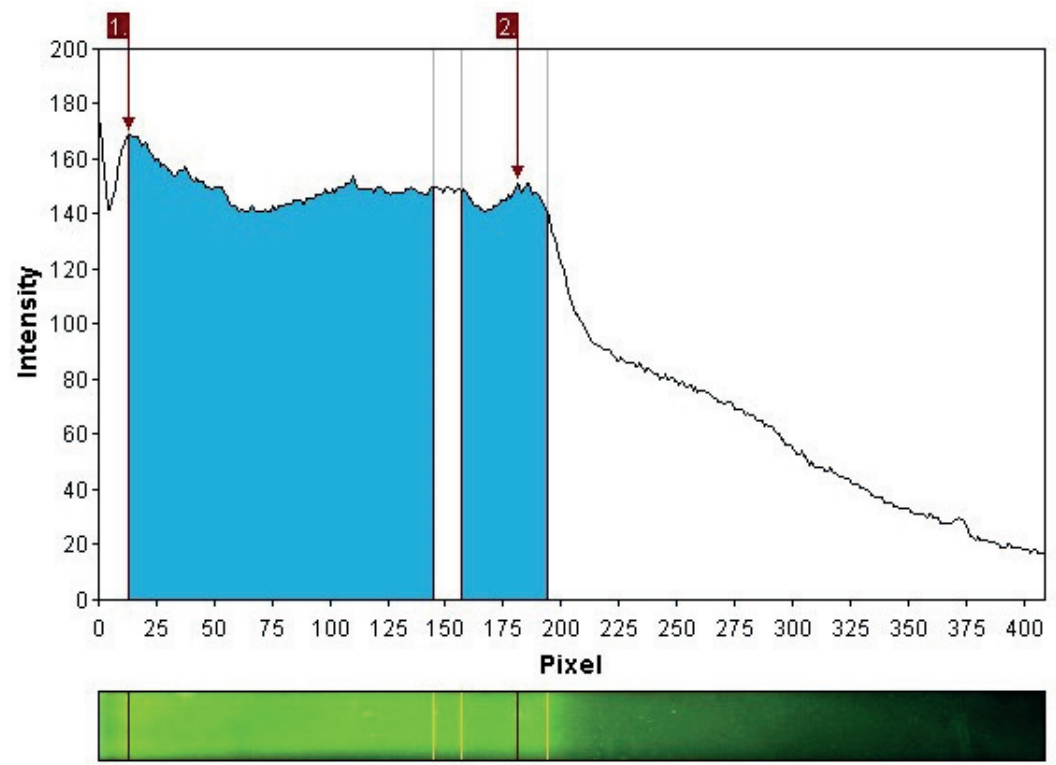

Fig. 4. Spectrogram of the protein composition of the diagnostic allergen Dermatophagoides pteronyssinus.

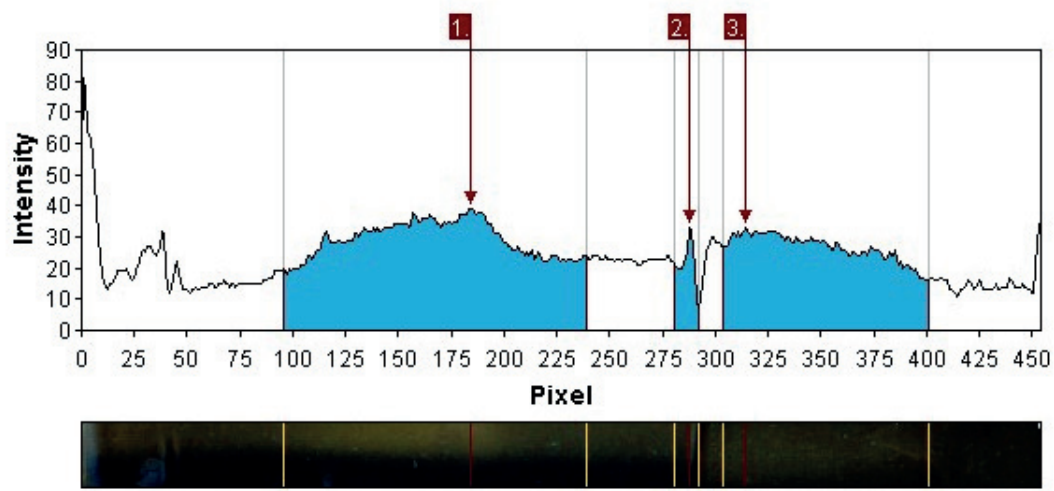

Fig. 5. Spectrogram of the protein composition of the diagnostic allergen mite Acarus siro.

mark 2. In addition, the spectrogram contains nonallergenic ballast protein components with a molecular weight of 20-40 (mark 1) and 8-12 kDa (mark 3).

The spectrogram of the protein composition of the diagnostic allergen of dog hair is presented in Fig. 5.
Analysis of the spectrogram showed that the protein composition of the allergen contains a major component of Can f1 (lipocalin) with a molecular weight of $23 \mathrm{kDa}$ (mark 3), minor components of Can f2 (19 $\mathrm{kDa}$ ) (mark 4) and Can f3 (69 kDa) (mark 1). In addi-
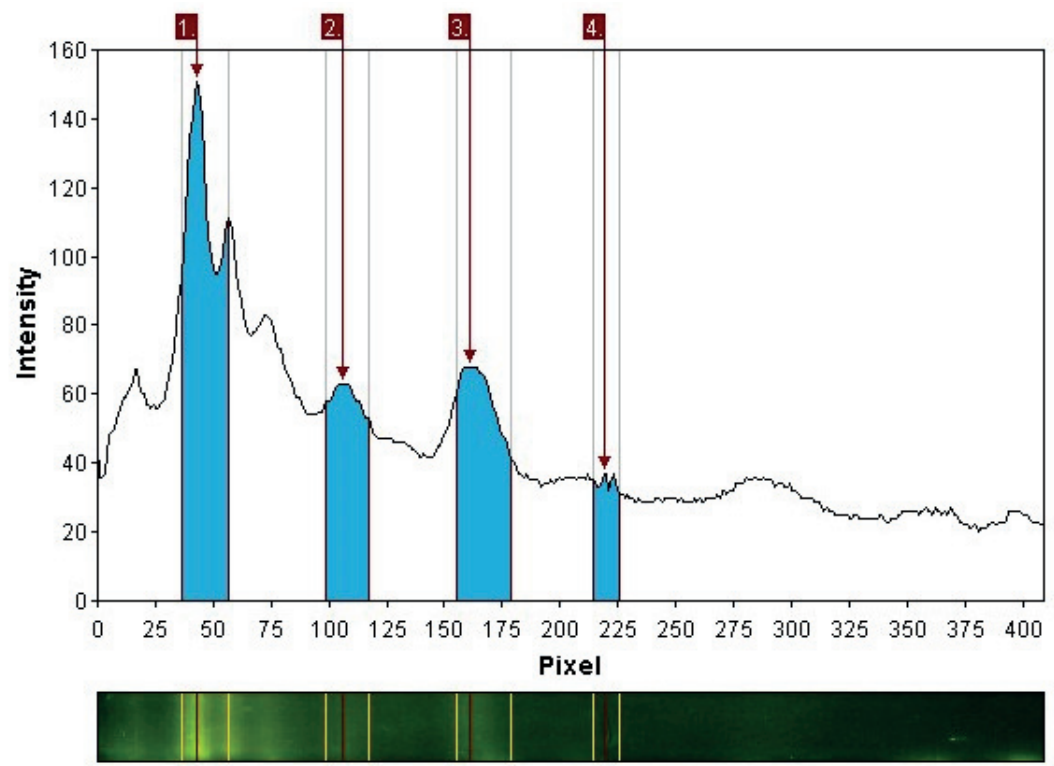

Fig. 6. Spectrogram of the protein composition of the diagnostic allergen of dog hair. 


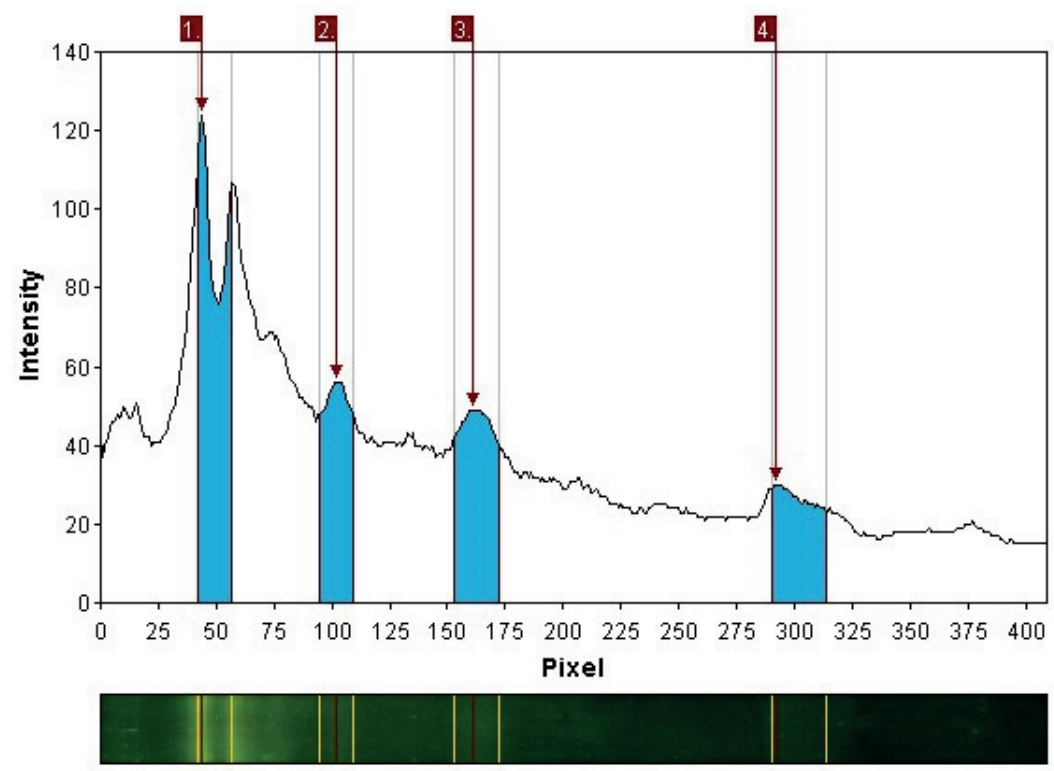

Fig. 7. Spectrogram of the protein composition of the diagnostic allergen of cat hair.

tion, the spectrogram contains non-allergenic ballast protein with a molecular weight of about $34-36 \mathrm{kDa}$ (mark 2).

The spectrogram of the protein composition of the diagnostic allergen of cat hair is given in Fig. 6.

.Analysis of the spectrogram showed that the protein composition of the allergen contains a major component of Fel d1 with a molecular weight of $38 \mathrm{kDa}$ (mark 2), a major component of Fel d4 (22 kDa) (mark $3)$, minor components of Fel d2 (69 kDa) (mark 1) and Fel d3 (11 kDa) (mark 4).

The spectrogram of the protein composition of the diagnostic allergen of sheep wool is shown in Fig. 7.

Analysis of the spectrogram shows that the diagnostic allergen of sheep wool is a set of protein molecules of different molecular weight from $25 \mathrm{kDa}$ to $90 \mathrm{kDa}$ (marks 1-7) with no clear peaks, and therefore it is not possible to estimate the component composition.

\section{Discussion}

Most diagnostic allergen extracts have been found to contain major and some minor protein components. However, not all important major components have been identified (eg, Der p2 and Der f2). This may be important for the diagnosis of sensitization in patients with IgE-dependent diseases, because in the presence of sensitivity to these components (and according to studies, it can be up to $75 \%$ of patients) the diagnostic results may not be completely reliable [8].

In addition, some of the allergen extracts contained a significant amount of ballast non-allergenic protein components, which are not important in skin testing, however, affect the total number of PNU, which is the standardization of allergens. Currently, the procedure of standardization of diagnostic allergens, common in a number of Eastern European

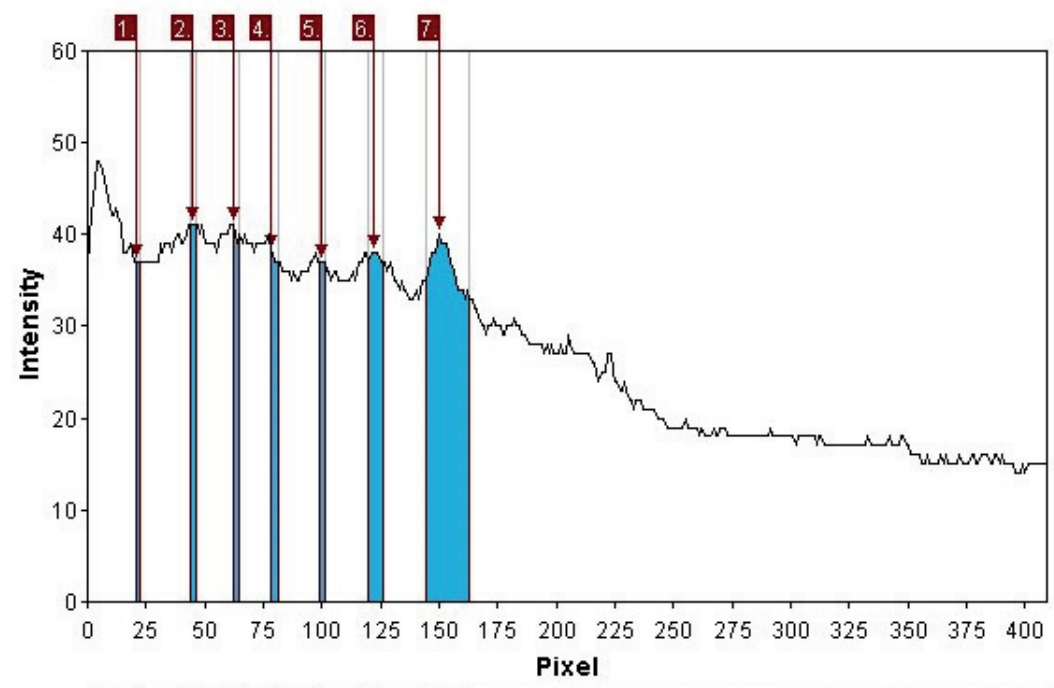

Fig. 7. Spectrogram of the protein composition of the diagnostic allergen of sheep wool. 
countries, including Ukraine, requires correction and transition to standardization of the component composition of extracts.

\section{Conclusions}

Analysis of spectrograms of diagnostic allergen extracts show the presence of major and minor components in most of the analyzed cases. Thus, for allergens of the mite group, Dermatophagoides pteronyssinus Der p1 with a molecular mass of $24 \mathrm{kDa}$, Dermatophagoides farinae - Der $\mathrm{f} 1$ with a molecular mass of 27 $\mathrm{kDa}$, Acarus siro - Aca s13 with a molecular mass of 15 $\mathrm{kDa}$ components were determined. For epidermal allergens, a major component of Can f1 (lipocalin) with a

\section{ЛITЕРАТУРА}

1. Frati F, Incorvaia C, Cavaliere C, et al. The skin prick test. J Biol Regul Homeost Agents. 2018;32(1 Suppl. 1):19-24. PMID:29552869.

2. Cho JH, Suh JD, Kim JK, HongSC, Park IH, Lee HM. Correlation between skinprick testing, individual specific IgE tests, and a multiallergen IgE assay for allergy detection in patients with chronic rhinitis. Am J Rhinol Allergy. 2014;28(5):388391. doi:10.2500/ajra.2014.28.4074.

3. Savi E, Peveri S, Cavaliere C, Masieri S, Montagni M. Laboratory tests for allergy diagnosis. J Biol Regul Homeost Agents. 2018;32(1 Suppl. 1):25-28. PMID:29552870.

4. Nevis IF, Binkley K, Kabali C. Diagnostic accuracy of skin-prick testing for allergic rhinitis: a systematic review and meta-analysis. Allergy Asthma Clin Immunol. 2016;12:20. doi:10.1186/s13223-016-0126-0.

5. Tourlas K, Burman D. Allergy Testing. Prim Care. 2016;43(3):363-374. doi:10.1016/j.pop.2016.04.001.

6. Carnés J, Iraola V, Cho SH, Esch RE. Mite allergen extracts and clinical practice. Ann Allergy Asthma Immunol. 2017;118(3):249-256. doi:10.1016/j. anai.2016.08.018.

7. Zimmer J, Vieths S, Kaul S. Standardization and Regulation of Allergen Products in the European Union. Curr Allergy Asthma Rep. 2016;16(3):21. doi:10.1007/s11882016-0599-4.

8. Tian M, Zhou Y, Zhang W, Cui Y. Der p 1 and Der $\mathrm{p} 2$ specific immunoglobulin E measurement for diagnosis of Dermatophagoides pteronyssinus allergy: A systematic review and meta-analysis. Allergy Asthma Proc. 2017; 38 (5): 333-342. doi: 10.2500 / aap.2017.38.4073. molecular mass of $23 \mathrm{kDa}$, a minor component of Can $\mathrm{f} 2(19 \mathrm{kDa})$ and Can f3 $(69 \mathrm{kDa})$ were found in dog hair allergen extract, and a major component of Fel d1 with a molecular mass of $38 \mathrm{kDa}$, major component Fel d4 $(22 \mathrm{kDa})$, minor components Fel d2 $(69 \mathrm{kDa})$ and Fel d3 $(11 \mathrm{kDa})$ were found in cat hair allergen extract.

For sheep wool allergen it is not possible to estimate the component composition by constructing a spectrogram after electrophoresis of solutions in polyacrylamide gel, as it is a mixture of proteins with similar molecular masses. In addition, a number of diagnostic allergens - dog hair, Dermatophagoides farinae, Dermatophagoides pteronyssinus - contains non-allergenic ballast proteins in solutions.

\section{REFERENCE}

1. Frati F, Incorvaia C, Cavaliere C, et al. The skin prick test. J Biol Regul Homeost Agents. 2018;32(1 Suppl. 1):19-24. PMID:29552869.

2. Cho JH, Suh JD, Kim JK, Hong SC, Park IH, Lee HM. Correlation between skinprick testing, individual specific IgE tests, and a multiallergen $\operatorname{IgE}$ assay for allergy detection in patients with chronic rhinitis. Am J Rhinol Allergy. 2014;28(5):388391. doi:10.2500/ajra.2014.28.4074.

3. Savi E, Peveri S, Cavaliere C, Masieri S, Montagni M. Laboratory tests for allergy diagnosis. J Biol Regul Homeost Agents. 2018;32(1 Suppl. 1):25-28. PMID:29552870.

4. Nevis IF, Binkley K, Kabali C. Diagnostic accuracy of skin-prick testing for allergic rhinitis: a systematic review and meta-analysis. Allergy Asthma Clin Immunol. 2016;12:20. doi:10.1186/s13223-016-0126-0.

5. Tourlas K, Burman D. Allergy Testing. Prim Care. 2016;43(3):363-374 doi:10.1016/j.pop.2016.04.001.

6. Carnés J, Iraola V, Cho SH, Esch RE. Mite allergen extracts and clinical practice. Ann Allergy Asthma Immunol. 2017;118(3):249-256. doi:10.1016/j. anai.2016.08.018.

7. Zimmer J, Vieths S, Kaul S. Standardization and Regulation of Allergen Products in the European Union. Curr Allergy Asthma Rep. 2016;16(3):21. doi:10.1007/s11882016-0599-4.

8. Tian M, Zhou Y, Zhang W, Cui Y. Der p 1 and Der p 2 specific immunoglobulin E measurement for diagnosis of Dermatophagoides pteronyssinus allergy: A systematic review and meta-analysis. Allergy Asthma Proc. 2017; 38 (5): 333-342. doi: 10.2500 / aap.2017.38.4073.

Надійшла до редакції 07.05.2020 p.

Прийнято до друку: 14.05.2020 р.

\author{
A. Є. Богомолов \\ ORCID iD \\ orcid.org/0000-0002-5336-4858
}

